\title{
Consumer Preferences for Cheese with Focus on Food Safety-A Segmentation Analysis
}

\author{
Edvin Zhllima ${ }^{1}$, Gentjan Mehmeti ${ }^{2, *}$ and Drini Imami ${ }^{1,3}$ (D) \\ 1 Department of Agrifood Economics and Policy, Agricultural University of Tirana, 1029 Tirana, Albania; \\ ezhllima@ubt.edu.al (E.Z.); dimami@ubt.edu.al (D.I.) \\ 2 Department of Agribusiness Management, Agricultural University of Tirana, 1029 Tirana, Albania \\ 3 Faculty of Tropical Agri Sciences, Czech University of Life Sciences, 16500 Prague, Czech Republic \\ * Correspondence: gmehmeti@ubt.edu.al
}

check for updates

Citation: Zhllima, E.; Mehmeti, G.; Imami, D. Consumer Preferences for Cheese with Focus on Food Safety-A Segmentation Analysis. Sustainability 2021, 13, 12524. https:// doi.org/10.3390/su132212524

Academic Editors: Marija Cerjak and Vlade Zarić

Received: 27 September 2021

Accepted: 9 November 2021

Published: 12 November 2021

Publisher's Note: MDPI stays neutral with regard to jurisdictional claims in published maps and institutional affiliations.

Copyright: (c) 2021 by the authors. Licensee MDPI, Basel, Switzerland. This article is an open access article distributed under the terms and conditions of the Creative Commons Attribution (CC BY) license (https:/ / creativecommons.org/licenses/by/ $4.0 /)$.

\begin{abstract}
This research work analyzes Albanian urban consumer preferences and purchasing behavior related to cheese, focusing on food safety and related attributes, including origin, packaging, and certification. This paper is based on a structured survey targeting urban consumers. The analysis consists of a two-step cluster and descriptive statistics. The clustering was based on key sociodemographic variables, namely, gender, education, and age. The results show that the local cheese is preferred to imported cheese, and the main sources of food safety guarantee are the producer name/brand and knowing the seller. Most consumers across all five identified clusters preferred buying unpacked cheese to packed cheese. The cluster of educated female consumers preferred to buy cheese mainly in supermarkets compared to other clusters that preferred convenience shops. Consumer clusters with a university education appeared to be more informed about both HACCP and ISO compared to other (less educated) consumer clusters. Low trust in state institutions to guarantee food safety calls for the need to strengthen their capacities, professionalism, and awareness engagement with consumers.
\end{abstract}

Keywords: consumer preferences; packaging; cheese; two-step cluster analysis; Albania

\section{Introduction}

One of the major concerns among consumers in developing or transition countries, characterized by weak law enforcement systems and limited resources, is food safety. The concerns are often more pronounced in the case of livestock products. Dairy and meat products have been considered problematic regarding compliance to food safety also in the case of Albania, a post-communist emerging economy, which is the focus of this paper [1,2].

In developed countries with consolidated institutions, consumers tend to trust public institutions to ensure food safety [3]. In the case of countries with weak food safety control systems, the level of trust in public institutions to ensure food safety tends to be lower and consumers may trust the retailer more than the public institutions. When possible, consumers often choose to buy food directly from producers to obtain higher safety and quality-consumers' trust is traditionally directly related to the short value chain [4].

Considering institutional conditions, consumers follow other type of indices to ensure food safety. Since food safety is a credence attribute, to achieve food safety consumers use cues that strengthen their trust in producers' processes. Consumers may rely on origin (domestic vs. imported and in the case of domestic, certain local area within the country where food is produced) and brand reputation to ensure food safety in decisions to purchase. According to a recent study, information about expiry date, knowing the producer or the brand name, and origin are the most frequently used food safety and quality cues for Albanian consumers [5].

Consumer buying behavior for food is influenced by various economic, cultural, psychological, and lifestyle factors [6]. Changes in lifestyle are also related to changes in 
the place of purchase. Many authors suggest that the growing culture of supermarkets and hypermarkets is associated with improvements in traceability systems and standards, and has also increased the need for packaged products. Furthermore, lifestyle changes for consumers prioritize convenience [7].

The development and modernization of food retail chains (including logistics) combined with rapid changes in consumer buying behavior in connection to increased income have caused the food retail market to grow rapidly [6]. On the other hand, packaging has received higher attention in the context of COVID-19-food packaging policies and practices have been subject to revision [8].

As highlighted earlier, livestock products, namely, meat and dairy products, are often exposed to food safety problems. There have been several studies on consumer awareness and concerns about food safety, which has been becoming increasingly important for consumers [9]. Food supply chain operators have to deal with growing food safety concerns, both reflected in increasing consumer expectations and also the legal and institutional requirements to meet the Albanian EU agenda on food safety. Furthermore, with the expansion of supermarket chains on the one hand, and the evolution of consumer preferences and lifestyles on the other, the Albanian agroindustry is struggling to strengthen its position in the retail market-especially in the case of livestock products due to food safety concerns and the strong competition from imports. This is particularly important in the case of dairy (and meat) products because they are key elements of the Albanian consumer basket-cheese is the main dairy product and one of the main food items in Albanian households $[10,11]$. Thus, having a better understanding of consumer perceptions and preferences related to food safety and quality in general, and to cheese specifically, is crucial—such an understanding may help food operators gain a competitive advantage through the successful implementation of sustainability practices [12].

This paper analyzes the consumer preferences towards key attributes related to the purchase of cheese products in Albania. The main objective is to explore Albanian consumer behavior and preferences for main product attributes such as packaging, place of purchase, and origin of the product (domestic or imported) in connection to food safety and to assess the relationship between consumer perception of these attributes and demographic characteristics of Albanian consumers.

The findings of this study are important considering that dairy products are an essential part of the household food basket and a backbone of the processing industry of livestock byproducts in many countries. Moreover, the dairy industry is one of the segments of the supply chain where quality and safety concerns occur most [13]. The importance for consumers is also crucial, especially in transition countries where, due to increasing incomes, price preferences are inferior to quality and safety concerns. The present study provides comprehensive knowledge on key factors of sustainable food safety, which appear critical to the effectiveness of the overall sustainable development of the society. Providing effective communication of food-related risks to consumers is crucial considering the emerging food safety threats [14]. The information on consumers' tactics in collecting information on food safety enables state agencies and other responsible actors to establish or revise the process of production, and achieving sustainability practices in food supply chains is expected to overcome such emerging challenges [12]. An important aspect of sustainability is the application of governance practices at the firm level. The implementation of such practices, especially for the agri-food sector, has a significant impact on the performance of firms/businesses [15]. The study contributes by emphasizing this aspect, too.

The Section 2 provides the literature review, the Section 3 consists of the methods, the Section 4 shows the results, and the Section 5 consists of discussions and conclusions.

\section{Literature Review}

Consumer purchasing behavior is a complex process. Consumers are oriented between research, experience, and credence characteristics to evaluate the product before 
purchase, after purchase, and the implications it brings [16]. Consumer perception of food quality, which also applies to the case of cheese, is related to their experiences toward taste, perception of effects on health, interests to convenience, and understanding of the way it is produced [16]. In this regard, the information transmitted to the consumers through packaging is important. Information about dairy products, considering the impact they have on consumer health, often creates confusion, especially about the fat content [17]. In cases where the information provided about a product, which may be the information provided through the packaging, has inconsistencies, consumers tend to reduce the perception of reliability [18].

Packaging is one of the most valued factors in consumer decision-making, with essential weight in the purchasing process [19]. Cheese can be purchased packaged or unpackaged, and this can have an impact on the consumer preference for this product. Packaging creates the first impression [20], as the buyer first comes in contact with the packaging and then with the product itself [21]. The role of packaging for consumers is becoming the main tool for communication and branding [22]. Special attention should be paid to packaging elements for their impact on consumer feedback [23]. Color as a packaging element encourages consumers to appreciate the product more, especially for healthy products [24]. Thus, frequent changes to packaging elements can disorient the consumer, affecting the perception of brands [23].

The consumers also use packaging as an indicator of quality-they create a relationship of symmetry between packaging and product quality [19]. Alternatively, consumers may prefer unpackaged products (in the case of cheese) due to the possibility to observe the extrinsic features through the sensory experiences, visibility, or touch [25]. They can use circumstantial factors that guide their choice, such as color, texture, aroma and the size of objects [26]. A differentiation strategy for cheese product sellers is to present the entire product (uncut cheese wheel) on the counter and leave the seller to cut and roll the cheese at the customer's request $[27,28]$, a tactic that draws the attention to the fact that individual consumer characteristics such as customer involvement, experience, and time availability are important [29]. In this context, the sociodemographic factors such as age, gender, status, residence, and education are very important in understanding consumers' tactics and packaging demands.

There are fewer studies on the impact of sociodemographic factors on the packaging elements themselves [30]. According to a previous study on Polish consumers preferences for dairy products, age, gender, and level of education affect packaging preferences [30]. Other research work emphasized the role of gender and age in decision-making [31]. Verbal elements of packaging and place of origin are important elements for both female and male consumers. However, in the case of female consumers, the impact of visual aspects appears to be more important. The more educated people are, the more concerned they are with the information that appears on the packaging [31].

Another attribute that can be analyzed about food is the place of purchase. Consumers may choose products sold in supermarkets based on the perception that products are inspected and safe to consume, or they may be unaware of the hazards associated with consumption of uninspected cheese and choose supermarkets due to the availability of product diversity and convenience [32]. Some consumers prefer different grocery stores for a variety of reasons: Lack of items, prices and promotional campaigns, time constraints, impulse buying, and convenience are some reasons [33].

In establishing consumer preference for products, authors who have studied retail in South Africa suggest that consumers value convenience in retail units [34]. Supermarket comfort is related to the interior environment of the store, which refers to elements such as image, easy movement, cleanliness of shops, and attractive decor. Supermarkets should attract the attention of the consumers by offering a large number of alternatives not only in products but also in different quality categories. Since time is essential in supermarket purchases, supermarkets are created to increase the efficiency and speed of purchases [34]. For example, British consumers prefer to buy products in department stores and supermar- 
kets by staying loyal to those retail stores [35]. Indeed, more than $73 \%$ of British consumer decisions are made in shopping places like supermarkets and hypermarkets [22]. Other studies have found that many consumers prefer more traditional outlets [36]. However, food purchasing patterns differ across countries. For example, Indian consumers perceive that food markets offer lower prices and more shopping benefits compared to conventional stores, but are less satisfied with the service provided by them [6].

In creating the concept of food safety and quality, aspects such as research, experience, and reliability attributes are taken into account [37]. Origin can become an indication of safety if the product is provided by a country or region promoted for food safety or higher quality [38]. Various studies have been conducted on the reliability of imported food products and their impact on consumer preference [39]. A previous study found that consumers prefer domestic products compared to imported products and are more likely to pay more for local products (e.g., cheese)—for these consumers, information about the country of origin is important [39]. This attribute can be considered in communication, as consumers use packaging elements such as color as an indicator of product originality [24]. Previous research has shown a strong preference of Albanian consumers for domestic cheese [10], as origin is perceived an indicator of the quality and safety of food products [5].

Ethnocentric behavior refers to maintaining loyalty to locally produced goods [40]. Consumer preference for domestic products should be analyzed in the case of the existence of substitute products or similarity in the cultures of the countries from where the products are imported. In this respect, the authors have some contradictory conclusions regarding a study with Greek consumers [41]. The positive relationship between American consumer ethnocentrism and the tendency to buy local products is also suggested for cheese products [42].

An additional instrument for strengthening consumers' perception of safety is certification. Certification is a way to advance the consumer's trust in food safety. However, certification has not always achieved or significantly improved food safety perception for some products [43]. Previous research has found that other attributes are considered more important than certification by consumers [44]. For Albanian consumers, the brand reputation and the presence of standard certificates are more important in decision-making [5]. It is crucial, given the emergence of the concerns of risk from contamination in cheese and the presence of high microbic levels, to explore consumer understanding of cheese processing standards. ISO and HACCP (Hazard Analysis Critical Control Point), are two main types of protocols/certifications that guarantee the use of safe practices in producing cheese. The latter is an obligatory protocol for all cheese producers in many countries. However, considering the high informality in many transition or developing countries, HACCP is often a hypothetical attribute.

As mentioned earlier in this section, the consumer sociodemographic expresses particular differences on the perception of food safety. Consumers with a high income level and high education level perceive food safety as more important. This trend has also been observed for female consumers and the elderly [45]. According to a recent survey in Albania, in terms of gender differences, women and well-educated consumers pay more attention to verifying food safety information. There are differences also regarding age. Younger and female consumers pay more attention to ingredient lists or safety elements [5].

\section{Data and Methods}

\subsection{Sampling}

This study was based on a face-to-face survey with consumers. The survey was administered in the urban areas of Tirana-the capital, and the largest city and market in Albania. Data collection took place during November 2012. Interviews were carried out by students trained and supervised by the authors of this paper.

A total of 200 valid questionnaires were included in the analysis. Table 1 below provides data on key sociodemographic variables from the sample and population. Overall, the sample structure is similar to the population structure in terms of gender and age. 
Table 1. Main sociodemographic data for the survey respondents and Tirana's population.

\begin{tabular}{|c|c|c|c|}
\hline \multicolumn{2}{|c|}{ Indicator } & \multirow{2}{*}{$\begin{array}{c}\text { Survey Respondents } \\
53.0 \%\end{array}$} & \multirow{2}{*}{$\begin{array}{c}\text { Tirana Population } \\
50.1 \%\end{array}$} \\
\hline & Male & & \\
\hline Gender & Female & $47.0 \%$ & $49.9 \%$ \\
\hline \multirow{9}{*}{ Age } & $18-24$ & $19 \%$ & $20.6 \%$ \\
\hline & $31-35$ & $7.5 \%$ & $10.7 \%$ \\
\hline & $36-40$ & $12.5 \%$ & $11.4 \%$ \\
\hline & $41-45$ & $9.0 \%$ & $11.8 \%$ \\
\hline & $46-50$ & $14.5 \%$ & $10.5 \%$ \\
\hline & $51-55$ & $13.0 \%$ & $8.6 \%$ \\
\hline & $56-60$ & $8.5 \%$ & $6.7 \%$ \\
\hline & 61-64 & $7.0 \%$ & $6.5 \%$ \\
\hline & 65 and up & $9.0 \%$ & $13.3 \%$ \\
\hline
\end{tabular}

Source: field survey and [10].

\subsection{Two-Step Cluster Approach}

The consumer sample was classified through a two-step clustering technique, based on the main sociodemographic variables utilized as input factors. The two-step cluster analysis (SPSS statistical package) is an exploratory and unsupervised multivariate data analysis technique that enables the clustering of large data sets and considers both continuous and categorical variables in the same clustering procedure [46]. This method is based on a probabilistic approach - the clustering algorithm utilizes a likelihood distance measure as the similarity criterion, and the most suitable number of clusters is chosen on the basis of Schwarz's Bayesian inference criterion (BIC). One major advantage of this clustering procedure is that the influence of the researcher's subjectivity is reduced [47].

SPSS calculates the number of clusters/groups with the best fit, the BIC, and a silhouette coefficient. The silhouette coefficient is a measure of clustering quality that is independent from the number of clusters (K), and can be used to evaluate cluster validity.

Validity is based on either the concept of cohesion, the proximity among members of the same cluster (the higher, the better), or on the concept of separation, the proximity among members or centroids of the different clusters (the lower, the better). The main advantage of this approach is that different measures of cluster validity can be combined, which avoids an arbitrary choice in the event that they are contrasting. The optimal number of clusters (K) in a data set can be found by computing the silhouette coefficients, which are calculated according to the following equation:

$$
s_{i}=\left(b_{i}-a_{i}\right) / \max \left(a_{i}, b_{i}\right)
$$

where $a_{i}$ is a measure of cohesion (i.e., the average distance of the $i$ th object to all other objects in the same cluster and $b_{i}$ is a measure of separation (i.e., the average distance of the $i$ th object to all other objects in a different cluster). The higher the average silhouette coefficient (or the closer to 1), the "more appropriate" the clustering is [48]. A silhouette measure lower than 0.20 indicates a poor solution quality, values of more than 0.50 indicate a good solution, and intermediate values are acceptable [49-51].

A two-step cluster has been applied in many consumer studies, and this approach has also been applied in previous studies on Albanian consumers related to preferences for meat, olive oil, and organic food [2,51-53]. Other studies observing consumer purchasing, consumption, and related lifestyles have utilized this approach [54-56].

\subsection{Sociodemographic Segmentation}

In this section of the analysis, typical sociodemographic variables were utilized as clustering variables, such as gender, education, and age. A five-cluster solution was obtained with a relatively high silhouette coefficient (0.6), indicating acceptable clustering for further analysis (see Figure 1 below for a visual illustration of the clustering quality). 


\section{Model Summary}

\begin{tabular}{|l|l|}
\hline Algorithm & TwoStep \\
\hline Inputs & 3 \\
\hline Clusters & 5 \\
\hline
\end{tabular}

\section{Cluster Quality}

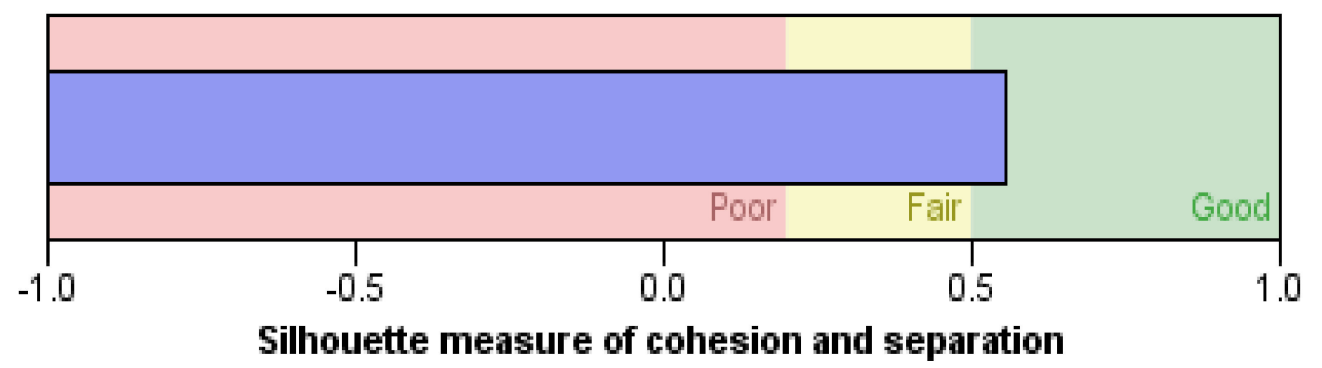

Figure 1. Model summary.

The five-cluster solution is presented in Table 2. The following clusters were obtained:

- $\quad$ Cluster 1 (MEF:middle-educated female consumers): contributed to $17.5 \%$ of the whole sample. It consisted of only female consumers with high school education (normally $12-13$ years). The average age was 48 .

- $\quad$ Cluster 2 (HEF:high-educated female consumers): contributed to $24.5 \%$ of the sample. It consisted of only female consumers with university education. The average age was 38. This cluster can be named "educated female consumers."

- Cluster 3 (LE:low-education consumers): contributed to $13 \%$ of the whole sample. It is different from the other clusters, as both genders were included, and $61.5 \%$ were males. Most consumers in this cluster $(96 \%)$ had basic education (typically 8 years of education). The average age was 55.

- $\quad$ Cluster 4 (HEM:high-educated male consumers): contributed to $20.5 \%$ of the sample. It consisted of only male consumers with university education. The average age was 37. This cluster can be named "educated male consumers."

- Cluster 5 (MEM:middle-educated male consumers): contributed to $24.5 \%$ of the whole sample. It consisted of only male consumers with high school education. The average age was 48.

Table 2. Cluster analysis results, BIC $=15$, silhouette coefficient $=0.6$.

\begin{tabular}{cccccc}
\hline Input Variable & Cluster 1-MEF & Cluster 2-HEF & Cluster 3-LE & Cluster 4-HEM & Cluster 5-MEM \\
\hline Size & $17.5 \%(35)$ & $24.5 \%(49)$ & $13 \%(26)$ & $20.5 \%(41)$ & $24.5 \%(49)$ \\
Education & High school 100\% & University 100\% & Basic education 96\% & University 100\% & High school 100\% \\
Gender & Female 100\% & Female 100\% & Male 61.5\% & Male 100\% & Male 100\% \\
Age & 48 & 38 & 55 & 37 & 48 \\
\hline
\end{tabular}


The identified consumer segments/classes were further subject to assess differences in perceptions or behavior by applying Pearson's Chi-square.

\section{Results}

As highlighted earlier, consumers link various food characteristics to food safety. In this context, a clear understanding of the perceptions and importance for consumers for characteristics or attributes such as cheese origin, packaging, and place of purchase is important for both policymakers and private sector actors. Consumer cluster analysis enables market segmentation and fine-tuning of policies according to risk perceptions or behavior of different consumer groups.

Regarding origin, which is an important food attribute and often also linked to food safety (as highlighted above), the results show an overall strong preference for local cheese. More specifically, most respondents (about 95\%) preferred domestic to imported cheese (Table 3) - there were no statistically significant differences between the identified clusters.

Table 3. Preferred cheese origin.

\begin{tabular}{|c|c|c|c|}
\hline \multirow{2}{*}{ Indicator } & \multicolumn{2}{|c|}{ Origin } & \multirow{2}{*}{ Total } \\
\hline & Domestic & Imported & \\
\hline Count & 189 & 11 & 200 \\
\hline Percentage & $94.5 \%$ & $5.5 \%$ & $100 \%$ \\
\hline
\end{tabular}

Source: field survey.

Consumers were also asked about the main perceived source of food safety guarantee. The results show that the main sources of food safety guarantee were the producer name/brand and knowing the seller (Table 4). The trust in state institutions to guarantee food safety appeared to be very low. Similarly, the trust in the label/packaging (including information provided there) was also very low. There were no statistically significant differences between the identified clusters.

Table 4. The source of (food) safety guarantee for purchased cheese.

\begin{tabular}{ccc}
\hline Category & Frequency & Percentage \\
\hline Producer name/brand & 84 & $42 \%$ \\
Knowing the seller & 82 & $41 \%$ \\
State institutions/authorities & 13 & $7 \%$ \\
Packaging and labelling & 9 & $5 \%$ \\
Testing and taste & 5 & $3 \%$ \\
Other & 7 & $4 \%$ \\
Total & 200 & $100 \%$ \\
\hline
\end{tabular}

Source: field survey.

Another important factor for consumers was the place or outlet where cheese is bought, which can also be linked to food safety (perceptions). Clusters 2 and 4 (female and male consumers with university education, respectively) preferred to buy cheese mainly in supermarkets (Table 5). The other three clusters preferred primarily convenience (e.g., neighborhood) shops. 
Table 5. Main outlet where cheese is purchased/sourced.

\begin{tabular}{|c|c|c|c|c|c|c|c|}
\hline \multirow{2}{*}{ Cluster } & \multirow{2}{*}{ Indicator } & \multicolumn{5}{|c|}{ Place of Buying Cheese } & \multirow[t]{2}{*}{ Total } \\
\hline & & Dairy Shop & Supermarket & Convenience Shop & Dairy Factory & Other & \\
\hline \multirow{2}{*}{ Cluster $1-\mathrm{MEF}$} & Count & 9 & 5 & 18 & 0 & 3 & 35 \\
\hline & Percentage & $25.7 \%$ & $14.3 \%$ & $51.4 \%$ & $0.0 \%$ & $9 \%$ & $100 \%$ \\
\hline \multirow{2}{*}{ Cluster 2-HEF } & Count & 11 & 25 & 8 & 1 & 4 & 49 \\
\hline & Percentage & $22.4 \%$ & $51.0 \%$ & $16.3 \%$ & $2.0 \%$ & $8 \%$ & $100 \%$ \\
\hline \multirow{2}{*}{ Cluster 3-LE } & Count & 5 & 1 & 12 & 1 & 7 & 26 \\
\hline & Percentage & $19.2 \%$ & $3.8 \%$ & $46.2 \%$ & $3.8 \%$ & $27 \%$ & $100 \%$ \\
\hline \multirow{2}{*}{ Cluster 4-HEM } & Count & 6 & 14 & 11 & 4 & 6 & 41 \\
\hline & Percentage & $14.6 \%$ & $34.1 \%$ & $26.8 \%$ & $9.8 \%$ & $15 \%$ & $100 \%$ \\
\hline \multirow{2}{*}{ Cluster 5-MEM } & Count & 11 & 10 & 18 & 0 & 10 & 49 \\
\hline & Percentage & $22.4 \%$ & $20.4 \%$ & $36.7 \%$ & $0.0 \%$ & $20 \%$ & $100 \%$ \\
\hline \multirow{3}{*}{ Total } & Count & 42 & 55 & 67 & 6 & 30 & 200 \\
\hline & Percentage & $21.0 \%$ & $27.5 \%$ & $33.5 \%$ & $3.0 \%$ & $15 \%$ & $100 \%$ \\
\hline & \multicolumn{6}{|c|}{$\begin{array}{l}21.0 \% \\
\text { Pearson's Chi-square } p \text {-value }=0.000\end{array}$} & \\
\hline
\end{tabular}

Source: field survey.

About $91 \%$ of the consumers stated that they usually buy unpacked cheese (thus only $9 \%$ usually buy packed cheese). When asked about their preferences, almost $25 \%$ of the consumers stated that they prefer to buy packed cheese (Table 6). Consumers belonging to the HEF and HEM clusters (female and male consumers with university education, respectively) were more inclined towards packed cheese, although even within those two clusters, the majority preferred to purchase unpacked cheese.

Table 6. Preference for packaging of purchased cheese.

\begin{tabular}{|c|c|c|c|c|}
\hline \multirow{2}{*}{ Cluster } & \multirow{2}{*}{ Indicator } & \multicolumn{2}{|c|}{ Type } & \multirow{2}{*}{ Total } \\
\hline & & Packed & Not Packed & \\
\hline \multirow{2}{*}{ Cluster 1-MEF } & Count & 4 & 31 & 35 \\
\hline & Percentage & $11.4 \%$ & $88.6 \%$ & $100 \%$ \\
\hline \multirow{2}{*}{ Cluster 2-HEF } & Count & 20 & 29 & 49 \\
\hline & Percentage & $40.8 \%$ & $59.2 \%$ & $100 \%$ \\
\hline \multirow{2}{*}{ Cluster 3-LE } & Count & 4 & 22 & 26 \\
\hline & Percentage & $15.4 \%$ & $84.6 \%$ & $100 \%$ \\
\hline \multirow{2}{*}{ Cluster 4-HEM } & Count & 12 & 29 & 41 \\
\hline & Percentage & $29.3 \%$ & $70.7 \%$ & $100 \%$ \\
\hline \multirow{2}{*}{ Cluster 5-MEM } & Count & 9 & 40 & 49 \\
\hline & Percentage & $18.4 \%$ & $81.6 \%$ & $100 \%$ \\
\hline \multirow{3}{*}{ Total } & Count & 49 & 151 & 200 \\
\hline & Percentage & $24.5 \%$ & $75.5 \%$ & $100 \%$ \\
\hline & \multicolumn{4}{|c|}{ Pearson's Chi-square $p$-value $=0.012$} \\
\hline
\end{tabular}

Source: field survey.

Although ISO and HACCP are common in Albania, and that information is often found on food labels, most consumers were not aware of HACCP, but tended to be more familiar with ISO standards (Table 7). The clusters of consumer with university education appeared to be more informed about both HACCP and ISO when compared to other (less educated) consumer clusters. 
Table 7. Answers to the question, "Do you know / are you aware of ISO and HACCP?".

\begin{tabular}{|c|c|c|c|c|c|c|c|}
\hline \multirow{2}{*}{ Cluster } & \multirow{2}{*}{ Indicator } & \multicolumn{3}{|c|}{ НАССР } & \multicolumn{3}{|c|}{ ISO } \\
\hline & & Yes & No & Total & Yes & No & Total \\
\hline \multirow{2}{*}{ Cluster 1} & Count & 2 & 33 & 35 & 16 & 19 & 35 \\
\hline & Percentage & $6 \%$ & $94 \%$ & $100 \%$ & $46 \%$ & $54 \%$ & $100 \%$ \\
\hline \multirow{2}{*}{ Cluster 2} & Count & 22 & 27 & 49 & 36 & 13 & 49 \\
\hline & Percentage & $45 \%$ & $55 \%$ & $100 \%$ & $73 \%$ & $27 \%$ & $100 \%$ \\
\hline \multirow[b]{2}{*}{ Cluster 3} & Count & 1 & 25 & 26 & 4 & 22 & 26 \\
\hline & Percentage & $4 \%$ & $96 \%$ & $100 \%$ & $15 \%$ & $85 \%$ & $100 \%$ \\
\hline \multirow{2}{*}{ Cluster 4} & Count & 19 & 22 & 41 & 28 & 13 & 41 \\
\hline & Percentage & $46 \%$ & $54 \%$ & $100 \%$ & $68 \%$ & $32 \%$ & $100 \%$ \\
\hline \multirow{2}{*}{ Cluster 5} & Count & 3 & 46 & 49 & 22 & 27 & 49 \\
\hline & Percentage & $6 \%$ & $94 \%$ & $100 \%$ & $45 \%$ & $55 \%$ & $100 \%$ \\
\hline \multirow{2}{*}{ Total } & Count & 47 & 153 & 200 & 106 & 94 & 200 \\
\hline & Percentage & $24 \%$ & $77 \%$ & $100 \%$ & $53 \%$ & $47 \%$ & $100 \%$ \\
\hline \multicolumn{2}{|c|}{$\begin{array}{l}\text { Pearson's Chi-square } \\
\quad p \text {-value }\end{array}$} & \multicolumn{3}{|c|}{ Chi-square $=0.000$} & \multicolumn{3}{|c|}{ Chi-square $=0.000$} \\
\hline
\end{tabular}

\section{Discussion of the Results and Conclusions}

This research provides an in-depth understanding of consumer perceptions and aspects related to purchasing behavior. In the sociodemographic segmentation, based on a two-step cluster analysis, gender, education, and age were used as input clustering variables. Five clusters with significant differences related to gender and education were obtained.

Overall, there was a strong preference for domestic cheese over imported cheese for the vast majority of surveyed consumers. This finding is in line with previous research that showed a strong preference of Albanian consumers for domestic cheese [10].

The majority of Albanian urban consumers preferred to buy cheese in convenience shops. That preference is linked to the fact that for many consumers, developing direct trusted relations is crucial to obtain safe and quality products, and that is only feasible for convenience stores-direct personal relations are not very likely to be developed with supermarket chain employees.

Most consumers across all identified clusters usually bought unpacked cheese and preferred to continue buying this unpacked cheese over packed cheese. Testing the product and experiencing extrinsic features from the product in bulk may be much more helpful to consumers looking for quality, compared to the information illustrated on the packaging or other elements of safety emerging from it. Consumers belonging to the two clusters dominated by educated consumers had a tendency to purchase packed cheese. Nevertheless, even within these two clusters the majority preferred unpacked cheese. The preferences on unpacked cheese, despite being a measure to control cheese safety and quality in densely urban areas, may become a risk factor for further food contamination. The emerging behaviors of educated consumers is a signal of opportunity for producers in pursuing market segmentation strategy. Producers may be advisable to provide to urban consumers an increasing share of production packaged. Particular attention to packaging should emphasize information on traceability and cheese content elements, therefore strengthening attributes of the credence of the product. Low-educated or traditional consumers can be provided cheese unpackaged with labelled large containers, which complies with their traditional purchasing behaviors.

Regarding $\mathrm{HACCP}$, most consumers were not aware of it-the clusters of consumers with university education appeared to be more informed about both HACCP and ISO compared to other (less educated) consumer clusters). Low consumer awareness on $\mathrm{HACCP}$, although is obligatory required to producers by the state institutions to guarantee food safety, calls for the need to strengthen consumer education and information, increase National Food Authority capacities, professionalism and accountability toward consumers. 
The findings of this study provide useful information for the Albanian dairy industry as well as for policymakers. Dairy industry managers should take into consideration the orientation of Albanian consumers toward quality and safety. On the other hand, policymakers and law enforcement institutions should ensure traceability, transparence and rigorous labelling of cheese, providing complete and reliable information on origin. Communication strategies about domestic food safety and quality from policymakers or companies can target female consumers, and better educated consumers/higher income consumers, since they showed higher awareness about food safety and quality [57].

One limitation is that the survey data are rather old. Future research should assess the evolution/changes of consumer behavior in times of COVID-19, considering the potential impact that the pandemic may have (had) on consumer perceptions related to food safety and origin [58].

Author Contributions: Conceptualization, E.Z., D.I. and G.M.; methodology, D.I., E.Z. and G.M.; validation, E.Z., G.M. and D.I.; data analysis, D.I., E.Z. and G.M.; writing, E.Z., G.M. and D.I.; visualization, G.M. All authors have read and agreed to the published version of the manuscript.

Funding: This research was funded by the USAID Albania/Hawai'i Higher Education and Economic Development (AHEED) Mini-Grant Program 2011.

Institutional Review Board Statement: Not applicable.

Informed Consent Statement: Not applicable.

Data Availability Statement: Not applicable.

Acknowledgments: The authors thank Sean Mason for his support and comments.

Conflicts of Interest: The authors declare no conflict of interest.

\section{References}

1. Verçuni, A.; Zhllima, E.; Imami, D.; Bijo, B.; Hamiti, X.h.; Bicoku, Y. Analysis of Consumer Awareness and Perceptions about Food Safety in Tirana, Albania. Albanian J. Agric. Sci. 2016, 15, 19-26.

2. Zhllima, E.; Imami, D.; Canavari, M. Consumer perceptions of food safety risk: Evidence from a segmentation study in Albania. J. Integr. Agric. 2015, 14, 1142-1152. [CrossRef]

3. Imami, D.; Valentinov, V.; Skreli, E. Food Safety and Value Chain Coordination in the Context of a Transition Economy: The Role of Agricultural Cooperatives. Int. J. Commons 2021, 15, 21-34. [CrossRef]

4. Food Agricultural Organisation (FAO). Smallholders and Family Farms in Albania; Country study report 2019; Food Agricultural Organisation: Quebec, QC, Canada, 2020.

5. Haas, R.; Imami, D.; Miftari, I.; Ymeri, P.; Grunert, K.; Meixner, O. Consumer Perception of Food Quality and Safety in Western Balkan Countries: Evidence from Albania and Kosovo. Foods 2021, 10, 160. [CrossRef]

6. Yadav, R.K.; Verma, M. Consumer Preference Towards Retail Stores for Food and Grocery in Evolving Retail Market. Int. Lett. Soc. Humanist. Sci. 2015, 60, 102-111. [CrossRef]

7. Goyal, A.; Singh, N.P. Consumer perception about fast food in India: An exploratory study. Br. Food J. 2007, 109, 182-195. [CrossRef]

8. Končar, J.; Marić, R.; Vukmirović, G.; Vučenović, S. Sustainability of Food Placement in Retailing during the COVID-19 Pandemic. Sustainability 2021, 13, 5956. [CrossRef]

9. Grunert, K.G.; Haas, R.; Imami, D.; Miftari, I. The effect of consumers' supermarket competence on information search and shopping outcomes in two Balkan cities. Q Open 2021, 1, 1. [CrossRef]

10. Imami, D.; Zhllima, E.; Merkaj, E.; Chan-Halbrendt, C.; Canavar, M. Albanian consumer preferences for the use of dry milk in cheese-making: A conjoint choice experiment. Agric. Econ. Rev. 2016, 17, 20-33.

11. Imami, D.; Skreli, E.; Zhllima, E.; Canavari, M.; Chan, C.; Cela, A. Analysis of consumers' preferences for typical local cheese in Albania applying conjoint analysis. New Medit 2016, 15, 49.

12. Ghadge, A.; Kara, M.E.; Mogale, D.G.; Chhoudhary, S.; Dani, S. Sustainability implementation challenges in food supply chains: A case of UK artisan cheese producers. Prod. Plan. Control 2021, 32, 1191-1206. [CrossRef]

13. Maitiniyazi, S.H.; Canavari, M. Understanding Chinese consumers' safety perceptions of dairy products: A qualitative study. Br. Food J. 2021, 123, 1837-1852. [CrossRef]

14. Flynna, K.; Villarreala, B.P.; Barrancoa, A.; Nastasia Belca, N.; Björnsdóttira, B.; Fuscoa, V.; Rainieria, S.; Smaradóttira, S.E.; Smeua, I.; Teixeiraa, P.; et al. An introduction to current food safety needs. Trends Food Sci. Technol. 2007, 84, 1-3. [CrossRef]

15. Conca, L.; Manta, F.; Morrone, D.; Toma, P. Effects of au naturel packaging colors on willingness to pay for healthy food. Bus. Strategy Environ. 2021, 30, 1080-1093. [CrossRef] 
16. Grunert, K.G. Food quality and safety: Consumer perception and demand. Eur. Rev. Agric. Econ. 2005, 32, 369-391. [CrossRef]

17. Sendra, E. Dairy Fat and Cardiovascular Health. Foods 2020, 9, 838. [CrossRef]

18. Bareket-Bojme, L.; Grinstein, A.; Steinhart, Y. Embrace the debate: Goals, de-marketing overconsumption, and conflicting information. Psychol. Mark. 2020, 37, 1484-1497. [CrossRef]

19. Silayoi, P.; Speece, M. Packaging and purchase decisions: An exploratory study on the impact of involvement level and time pressure. Br. Food J. 2004, 106, 607-628. [CrossRef]

20. Holmes, G.R.; Paswan, A. Consumer reaction to new package design. J. Prod. Brand Manag. 2012, 21, 109-116. [CrossRef]

21. Gofman, A.; Moskowitz, H.R. Accelerating structured consumer-driven package design. J. Consum. Mark. 2010, 27, 157-168. [CrossRef]

22. Rettie, R.; Brewer, C. The verbal and visual components of package design. J. Prod. Brand Manag. 2000, 9, 56-70. [CrossRef]

23. Orth, U.R.; Rose, G.M.; Merchant, A. Preservation, rejuvenation or confusion? Changing package design for heritage brands. Psychol. Mark. 2019, 36, 831-843. [CrossRef]

24. Marozzo, V.; Raimondo, M.A.; Miceli, G.N.; Scopelliti, I. Effects of au naturel packaging colors on willingness to pay for healthy food. Psychol. Mark. 2020, 37, 913-927. [CrossRef]

25. Holbrook, M.B.; Hirschman, E.C. The experiential aspects of consumption: Consumer fantasies, feelings, and fun. J. Consum. Res. 1982, 9, 132-140. [CrossRef]

26. Galotti, K.M. Cognitive Psychology in and out of the Laboratory, 2nd ed.; Brooks/Cole Publishing Company: Pacific Grove, CA, USA, 1994.

27. Colonna, A.; Durham, C.; Meunier-Goddik, L. Factors affecting consumers' preferences for and purchasing decisions regarding pasteurized and raw milk specialty cheese. J. Dairy Sci. 2011, 94, 10. [CrossRef]

28. Bloch, P. Seeking the Ideal Form: Product Design and Consumer Response. J. Mark. 1995, 59, 16-29. [CrossRef]

29. Silayoi, P.; Speece, M. The importance of packaging attributes: A conjoint analysis approach. Eur. J. Mark. 2007, 41, 1495-1517. [CrossRef]

30. Baruk, A.I.; Iwanicka, A. The effect of age, gender and level of education on the consumer's expectations towards dairy product packaging. Br. Food J. 2016, 118, 100-118. [CrossRef]

31. Barber, N.; Almanza, B.A.; Donovan, J.R. Motivational factors of gender, income and age on selecting a bottle of wine. Int. J. Wine Mark. 2006, 18, 218-232. [CrossRef]

32. Planzer, S.B., Jr.; Da Cruz, A.G.; Sant'Ana, A.S.; Silva, R.; Moura, M.R.L.; De Carvalho, L.M.J. Food Safety Knowledge of Cheese Consumers. J. Food Sci. 2009, 74, 1. [CrossRef]

33. Skallerud, K.; Korneliussen, T.; Olsen, S.O. An examination of consumers' cross-shopping behaviour. J. Retail. Consum. Serv. 2009, 16, 181-189. [CrossRef]

34. Terblanche, N.S.; Boshoff, C. The in-store shopping experience: A comparative study of supermarket and clothing store customers. S. Afr. J. Bus. Manag. 2004, 35, 1-10. [CrossRef]

35. Dunn, R.; Neil Wrigley, D. Store loyalty for grocery products: An empirical study. R. Geogr. Soc. Inst. Br. Geogr. 1984, 16.4, 307-314.

36. Center, Food Processing. The Specialty Cheese Market; Food Processing Center, Institute of Agriculture and Natural Resources, University of Nebraska: Lincoln, NE, USA, 2001. Available online: https://digitalcommons.unl.edu/fpcreports/9/ (accessed on 22 June 2021).

37. Anderson, J.G.; Anderson, J.L. Seafood Quality: Issues for Consumer Research. J. Consum. Aff. 1991, 25, 144-163. [CrossRef]

38. Loureiro, M.L.; Umberger, W.J. A choice experiment model for beef: What US consumer responses tell us about relative preferences for food safety, country-of-origin labeling and traceability. Food Policy 2007, 32, 496-514. [CrossRef]

39. Gedikoglua, H.; Parcell, J.L. Variation of Consumer Preferences Between Domestic and Imported Food: The Case of Artisan Cheese. J. Food Distrib. Res. 2014, 45, 174-194.

40. Shimp, T.; Sharma, S. Consumer Ethnocentrism: Construction and Validation of the CETSCALE. J. Mark. Res. 1987, 24, 280-289. [CrossRef]

41. Krystallis, A.; Chryssochoidis, G. Does the Country-of-Origin (COO) of Food Products Influence Consumer Evaluations? An Empirical Examination of Ham and Cheese. In Proceedings of the 98th EAAE Seminar Marketing Dynamics within the Global Trading System: New Perspectives, Chania, Crete, Greece, 29 June-2 July 2006.

42. Van Loo, E.J.; Caputo, V.; Lusk, J.L. Consumer preferences for farm-raised meat, lab-grown meat, and plant-based meat alternatives: Does information or brand matter? Food Policy 2019, 95, 101931. [CrossRef]

43. Corcoran, K.; Bernués, A.; Manrique, E.; Pacchioli, T.; Baines, R.; Boutonnet, J.P. Current consumer attitudes towards lamb and beef in Europe. Options Méditerranéennes A 2001, 46, 75-79.

44. Tendero, A.; Rodolfo Bernabe'u, R. Preference structure for cheese consumers A Spanish case study. Br. Food J. 2005, 107, 60-73. [CrossRef]

45. Goktolga, Z.G.; Bal, S.G.; Karkacier, O. Factors effecting primary choice of consumers in food purchasing: The Turkey case. Food Control 2006, 17, 884-889. [CrossRef]

46. Chiu, T.; Fang, D.; Chen, J.; Wang, Y.; Jeris, C. A robust and scalable clustering algorithm for mixed type attributes in large database environment. In Proceedings of the Seventh ACM SIGKDD International Conference on Knowledge Discovery and Data Mining, San Francisco, CA, USA, 26-29 August 2001; pp. 263-268. 
47. Norusis, M.J. SPSS 12.0 Statistical Procedures Companion; Prentice-Hall: Upper Saddle River, NJ, USA, 2003.

48. Al-Zoubi, M.; Al Rawi, M. An efficient approach for computing silhouette coefficients. J. Comput. Sci. 2008, 4, 252-255. [CrossRef]

49. Mooi, E.A.; Sarstedt, M. A Concise Guide to Market Research. In The Process, Data, and Methods Using IBM SPSS Statistics; Springer: Berlin/Heidelberg, Germany, 2011.

50. Kaufman, L.; Rousseeuw, P.J. Finding Groups in Data: An Introduction to Cluster Analysis; John Wiley \& Sons: Hoboken, NJ, USA, 1990; No. 519.53 K21.

51. Imami, D.; Zhllima, E.; Skreli, E. Analyzing Consumer Awareness and Perceptions about Food Safety in the Context of a European Transition Country Applying Segmentation Approach. J. Econ. Agribus. 2020, 13, 14-28.

52. Imami, D.; Zhllima, E.; Canavari, M.; Merkaj, E. Segmenting Albanian consumers according to olive oil quality perception and purchasing habits. Agric. Econ. Rev. 2013, 14, 97-112.

53. Imami, D.; Skreli, E.; Zhllima, E.; Chanb, C. Consumer attitudes towards organic food in the Western Balkans-The case of Albania. Econ. Agro-Aliment. 2017, 19, 245-260. [CrossRef]

54. Geeroms, N.; Verbeke, W.; Kenhove, P.V. Health advertising to promote fruit and vegetable intake: Application of health-related motive segmentation. Food Qual. Prefer. 2008, 19, 481-497. [CrossRef]

55. Rong-Da Lianga, R.; Limb, W.M. Exploring the online buying behavior of specialty food shoppers. Int. J. Hosp. Manag. 2011, 30, 855-865. [CrossRef]

56. Żakowska-Biemans, S. Polish consumer food choices and beliefs about organic food. Br. Food J. 2011, 113, 122-137. [CrossRef]

57. Haas, R.; Imami, D.; Miftari, I.; Ymerie, P.; Grunert, K. How do Kosovar and Albanian consumers perceive food quality and safety in the dairy sector? Stud. Agric. Econ. 2019, 121, 119-126.

58. Miftari, I.; Cerjak, M.; Tomić-Maksan, M.; Imami, D.; Prenaj, V. Consumer ethnocentrism and preference for domestic wine in times of COVID-19. Stud. Agric. Econ. 2021, forthcoming. 